\title{
PENDUGAAN PEPTIDA BIOAKTIF DARI SUSU TERHIDROLISIS OLEH PROTEASE TUBUH DENGAN TEKNIK IN SILICO
}

\author{
[In Silico Prediction of Bioactive Peptides from Bovine Milk Hydrolyzed \\ by Human Gastrointestinal System Proteases]
}

\author{
Azis Boing Sitanggang ${ }^{1,2) \star}$, Sudarsono ${ }^{1)}$, dan Dahrul Syah ${ }^{1,2)}$ \\ 1) Departemen Ilmu dan Teknologi Pangan, Fakultas Teknologi Pertanian, Institut Pertanian Bogor, Bogor \\ 2) Southeast Asian Food and Agricultural Science and Technology (SEAFAST) Center, Institut Pertanian Bogor, Bogor
}

Diterima 22 Maret 2018 / Disetujui 21 Juni 2018

\begin{abstract}
The production of bioactive peptides catalyzed by gastrointestinal system (GIS) enzymes can be predicted in silico. The technique is more preferred than the others such as in vivo and in vitro due to its low cost and less tedious procedure. The current study was aimed to predict bioactive peptides resulted from the digestion of bovine milk proteins. The digestion or so-called hydrolysis was simulated by means of a web-based in silico method. The identified bovine milk proteins from the available literatures were aS1casein, $\alpha S 2$-casein, $\beta$-casein, $\kappa$-casein, $\beta$-lactoglobulin, $\alpha$-lactalbumin, and lactoferrin. The compositions of amino acids (AAs) or protein sequences were accessed and tabulated from the Universal Protein Resource site (UniProt). Furthermore, the hydrolysis of each protein were simulated using three (3) GIS proteases, i.e., pepsin, trypsin, and chymotrypsin, and their possible combinations. All simulations were performed through web-based procedures using PeptideCutter, Expert Protein Analysis System (ExPASy). The resulted peptides were arranged according to the positions of cleavage sites for each cutting simulation, and compared to the available bioactive peptides data base in the literatures in terms of their $A A$ residues (sequences). The simulation results indicated that $\beta$-casein and $\alpha S 1$-casein were the most potent proteins to yield bioactive peptides, of 52 and 48\%, respectively. Moreover, each type of the investigated bovine milk proteins could be hydrolyzed by GIS proteases to produce antihypertensive bioactive peptides. This web-based in silico method is conclusively useful to predict bioactive peptides derived from bovine milk, and may also be used for other protein sources.
\end{abstract}

Keywords: bioactive peptides, in silico, milk protein, peptide cutter

\begin{abstract}
ABSTRAK
Peptida bioaktif dapat dihasilkan dari hidrolisis protein maupun sintesis kimia. Pada jalur hidrolisis, metode in silico dapat digunakan sebagai alternatif agar pendugaan peptida bioaktif berlangsung lebih efektif dan efisien. Penelitian ini bertujuan menduga peptida bioaktif dari susu sapi yang termetabolisme menggunakan teknik in silico berbasis laman web. Berdasarkan studi literatur, jenis protein yang dominan dari susu adalah $\alpha \mathrm{S} 1$-kasein, $\alpha \mathrm{S} 2$-kasein, $\beta$-kasein, $\mathrm{k}$-kasein, $\beta$-laktoglobulin, $\alpha$-laktalbumin, dan laktoferin. Rangkaian (sekuen) dan komposisi asam amino dari setiap jenis protein di atas didapatkan dari laman Universal Protein Resource (UniProt). Hidrolisis atau pemotongan dari setiap sekuen protein disimulasikan menggunakan enzim protease tubuh manusia, yakni pepsin, tripsin, dan kimotripsin maupun kombinasinya yang tersedia pada laman Peptide Cutter portal Expert Protein Analysis System (ExPASy). Peptida-peptida hasil pemotongan dengan teknik in silico ini kemudian disusun berurutan berdasarkan posisi pemotongan untuk setiap simulasi pemotongan. Keberadaan peptida bioaktif hasil simulasi dapat diketahui dengan mencocokkan kesamaan komposisi asam amino dan sekuennya dengan pangkalan data peptida bioaktif yang terdapat pada literatur. Hasil simulasi menunjukkan bahwa $\beta$-kasein dan $\alpha$ S1-kasein merupakan protein-protein susu yang menghasilkan peptida bioaktif terbesar, yakni berturut-turut sebesar 52 dan $48 \%$. Selain itu, dengan metode ini didapatkan bahwa setiap protein susu dapat dihidrolisis untuk menghasilkan peptida yang memiliki aktivitas antihipertensi. Pendugaan produksi bioaktif dari protein susu dengan teknik in silico ini terbukti bermanfaat dan oleh karenanya metode ini dapat juga digunakan untuk menduga peptida bioaktif dari berbagai sumber protein lainnya.
\end{abstract}

Kata kunci: in silico, peptida bioaktif, pemotongan peptida, protein susu

*Penulis Korespondensi:

E-mail: boing.lipan@apps.ipb.ac.id 


\section{PENDAHULUAN}

Peptida bioaktif merupakan fragmen protein spesifik yang memiliki fungsi sebagai modulator dari berbagai proses regulasi di dalam tubuh sehingga berdampak positif pada kondisi tubuh (Sánchez dan Vázquez, 2017). Beberapa fungsi dari peptida bioaktif telah dilaporkan berkaitan dengan pertahanan imun tubuh, kesehatan tulang, pencernaan, gigi maupun untuk pengaturan berat badan (Korhonen, 2009a).

Penelitian pada dua dekade terakhir menunjukkan bahwa protein susu merupakan sumber atau perkusor yang baik untuk produksi atau sintesis peptida bioaktif (Nagpal et al., 2011). Sebagai sumber protein (parent proteins), protein susu mengandung sekuen atau rangkaian peptida yang belum aktif. Jika dikonsumsi, maka rangkaian asam amino tersebut dapat dihidrolisis in vivo oleh enzim proteolitik dari sistem pencernaan tubuh (gastrointestinal system/GIS proteases) yang dapat menghasilkan berbagai jenis peptida bioaktif (Choi et al., 2012). Peptida bioaktif susu juga dapat dihidrolisis secara in vitro menggunakan enzim proteolitik yang berasal dari berbagai mikroorganisme dan tumbuhan (Korhonen dan Pihlanto, 2007).

Penentuan dan pendugaan peptida bioaktif menggunakan teknik in vivo maupun in vitro umumnya membutuhkan biaya yang cukup besar dan waktu yang lebih lama. Oleh karena itu, teknik in vivo dan/atau in vitro sering kali digabungkan atau didahului dengan teknik in silico (sinergisme), sebagai upaya menurunkan biaya serta mempercepat waktu kuantifikasi (Sucher, 2014). Teknik in silico merupakan suatu metode eksperimen yang menggunakan pemodelan atau simulasi komputer (Ekins et al., 2007). Berdasarkan kemampuan komputasi yang meningkat secara eksponensial saat ini, memberikan peluang penggunaan teknik in silico untuk mengembangkan simulasi dan kalkulasi dalam merancang atau mengidentifikasi berbagai senyawa termasuk di bidang ilmu dan teknologi pangan ( $\mathrm{Gu}$ et al., 2011). Seiring dengan hal ini, maka secara spesifik pencarian dan penemuan protein atau peptida fungsional dapat dilakukan lebih cepat (Doytchinova et al., 2004).

Sejauh ini, penggunaan teknik in silico telah dilaporkan untuk mengkarakterisasi potensi $\beta$-laktoglobulin, $\alpha$-laktalbumin sebagai sumber peptida aktif yang dapat memodulasi fungsi inkretin (Tulipano et al., 2015). Identifikasi dan karakterisasi peptida bioaktif yang berasal dari keseluruhan protein susu menggunakan protease spesifik belum dilaporkan menggunakan teknik in silico. Oleh karena itu, penelitian ini bertujuan memanfaatkan teknik in silico berbasis laman web untuk menduga peptida bioaktif yang dihasilkan dari hidrolisis protein susu sapi (Bos taurus). Simulasi hidrolisis protein susu mengguna- kan enzim proteolitik yang berasal dari GIS (pepsin, tripsin, dan kimotripsin) dilakukan dalam berbagai strategi kombinasi enzim (individual maupun gabungan). Peptida hasil hidrolisis kemudian disusun berdasarkan lokasi pemotongannya, lalu komposisi asam amino (AA) dan urutan atau rangkaiannya dibandingkan dengan rangkaian peptida bioaktif yang telah dilaporkan, sehingga peptida bioaktif dari protein susu dapat diidentifikasi dan ditabulasikan.

\section{BAHAN DAN METODE}

\section{Bahan}

Bahan penelitian ini merupakan informasi elektronik yang berasal dari berbagai literatur (Apweiler, 2009; Bruni et al., 2016; Dziuba et al., 2009; Iwaniak dan Dziuba, 2011; Korhonen, 2009a; Korhonen, 2009b; Korhonen, 2011; Sánchez dan Vázquez, 2017) maupun situs bioinformatika berupa pangkalan data BIOPEP (http://www.uwm.edu.pl/biochemia) (diakses pada Januari 2017) dan situs Universal Protein Resource (UniProt) (http://www.uniprot.org) (diakses pada Januari 2017) yang memberikan akses atas berbagai data protein maupun proteomik.

\section{Alur penelitian}

Secara umum metode penelitian dapat dilihat pada Gambar 1. Penelitian ini dibagi menjadi beberapa tahapan yaitu: (1) identifikasi protein utama susu sapi, (2) identifikasi dan tabulasi peptida bioaktif (komposisi dan sekuen/rangkaian AA) yang telah dilaporkan pada pangkalan data, (3) Identifikasi dan tabulasi komposisi AA dan sekuen protein utama susu dengan utilitas Basic Local Alignment Search Tool (BLAST), (4) simulasi pemotongan protein sekuen menggunakan perangkat lunak PeptideCutter, (5) penyusunan peptida hasil pemotongan, dan (6) perhitungan persentase kecocokan antara peptida hasil pemotongan dengan pangkalan data sehingga didapatkan informasi peptida bioaktif susu in silico. Khusus untuk tahapan (1), informasi yang dikumpulkan berasal dari dari berbagai artikel dan buku hasil penelitian. Sedangkan untuk tahapan (2), selain berasal dari studi pustaka, informasi sekuen dan komposisi peptida aktif juga didapatkan dari pangkalan data BIOPEP (http://www.uwm.edu.pl/ biochemia) (Iwaniak dan Dziuba, 2011).

\section{Identifikasi komposisi asam amino dan sekuen protein susu dengan utilitas BLAST (Apweiler, 2009) [tahapan (3)] \\ Situs Universal Protein Resource (UniProt)} (http://www.uniprot.org) digunakan sebagai sumber informasi untuk mengidentifikasi komposisi asam amino dan sekuen dari protein susu yang telah didapatkan dari tahapan penelitian (1). UniProt merupakan suatu repositori untuk menyimpan dan menghu- 
bungkan informasi terkait protein dan proteomik (Apweiler, 2009). Situs UniProt dibuat dan diolah oleh Swiss Institute of Bioinformatics (SIB). Dari pangkalan data UniProt Knowledgebase (UniProt$\mathrm{KB})$, informasi $A A$ dapat dengan mudah diakses menggunakan utilitas BLAST. Teknik yang sama telah dilaporkan untuk mengidentifikasi sekuen protein dari enzim $\beta$-galaktosidase dari $A$. oryzae dan K. lactis (Sitanggang et al., 2016).

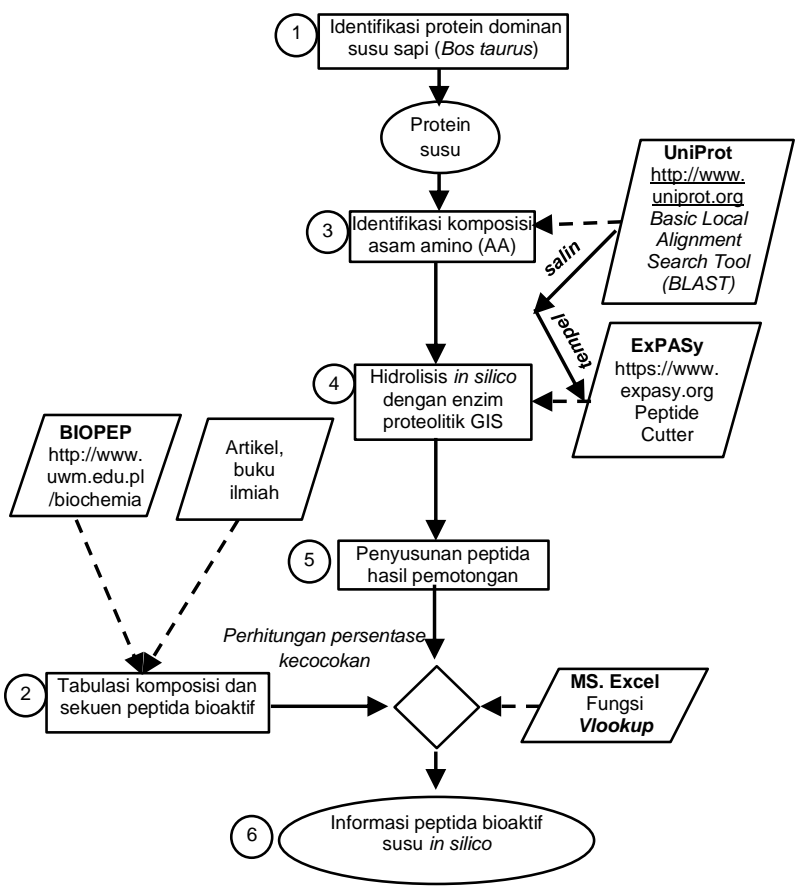

Keterangan: $\rightarrow=$ Tahapan proses; $\rightarrow=$ Informasi eksternal/utilitas

Gambar 1. Diagram alir metode penelitian

Simulasi pemotongan protein sekuen menggunakan perangkat lunak PeptideCutter (Gasteiger et al., 2003) [tahapan (4)]

Proteolisis atau pemotongan protein dilakukan menggunakan perangkat lunak PeptideCutter (http:// web.expasy.org/peptide_cutter/) yang tersedia pada portal Expert Protein Analysis System (ExPASy) Molecular Biology Server. Sama halnya dengan UniProt, ExPASy juga dikembangkan oleh SIB yang meliputi beberapa pangkalan data, yakni SWISSPROT dan TrEMBL, SWISS-2DPAGE, PROSITE, ENZYME dan repositori SWISS-MODEL (Gasteiger et al., 2003).

Simulasi pemotongan rangkaian $\mathrm{AA}$ yang didapatkan dari utilitas BLAST (UniProt) dapat langsung dilakukan pada portal PeptideCutter. Simulasi pemotongan protein susu ini dilakukan dengan menggunakan enzim proteolitik GIS, yakni pepsin ( $\mathrm{pH} 1.3)$, tripsin dan kimotripsin (spesifitas tinggi). Strategi pemotongan dilakukan pada berbagai kombinasi enzim, yakni (1) satu enzim, (2) kombinasi dua enzim, dan (3) kombinasi 3 enzim. Dalam hal ini, setiap protein susu akan dihidrolisis secara terpisah menggunakan tujuh (7) kombinasi enzim yakni: (i) pepsin, (ii) tripsin, (iii) kimotripsin, (iv) pepsin+tripsin, (v) pepsin +kimotripsin, (vi) tripsin+kimotripsin, dan (vii) pepsin +tripsin+kimotripsin.

Identifikasi peptida hasil pemotongan dan analisis aktivitas biologisnya [tahapan (5) dan (6)]

Identifikasi peptida hasil pemotongan in silico dan analisis bioaktivitasnya dicakup dalam tahapan penelitian (5) dan (6). Penyusunan peptida hasil simulasi pemotongan dilakukan secara manual berdasarkan jumlah titik potong (number of cleavages) dan posisi pemotongan (cleavages sites) untuk setiap simulasi. Selanjutnya, aktivitas biologis dari peptida hasil simulasi didapatkan dengan terlebih dahulu mencocokkan atau membandingkan komposisi AA dan sekuen peptida hasil simulasi dengan pangkalan data peptida bioaktif (hasil dari tahapan (2)). Pencocokan peptida hasil pemotongan terhadap pangkalan data peptida bioaktif dilakukan menggunakan fungsi vlookup yang tersedia pada perangkat lunak Microsoft Excel (www.microsoft.com/Office/ Suite).

\section{HASIL DAN PEMBAHASAN}

Hasil identifikasi protein utama dari susu dan sekuennya serta aktivitas biologis peptida bioaktif susu

Susu yang berasal dari sapi memiliki kandungan protein sebesar $3,5 \%$, dimana protein dominannya adalah dari golongan kasein $(80 \%)$ dan whey (laktoserum) (20\%) (Korhonen, 2009b). Karakteristik protein yang diduga sebagai sumber peptida bioaktif berdasarkan studi literatur adalah aS1kasein, aS2-kasein, $\beta$-kasein, dan k-kasein (golongan kasein) serta $\beta$-laktoglobulin, $\alpha$-laktaslbumin, dan laktoferin (golongan whey) (Korhonen, 2011). Berdasarkan penelusuruan pada laman UniProt menggunakan utilitas BLAST, karakteristik dan komposisi AA dari setiap protein susu tersebut dapat dilihat pada Tabel 1. Selain itu, berdasarkan studi literatur, terdapat 13 bioaktivitas peptida susu, yakni antihipertensi, antibakteri, antiamnestik, antikarsinogenik, antitrombotik, antioksidan (Dziuba et al., 2009), antivirus, imunomodulator (Gobbetti et al., 2002), regulator, inhibitor dipeptidil peptidase IV (DPP IV) (Korhonen, 2009a), pengikat mineral, opioid, serta opioid antagonis (Vercruysse et al., 2009). 
Tabel 1. Karakteristik dan komposisi asam amino (AA) dari protein susu menggunakan utilitas BLAST pada laman UniProt

\begin{tabular}{|c|c|c|c|c|}
\hline No. & Jenis Protein & $\begin{array}{l}\text { Kode, } \\
\text { Status }\end{array}$ & Komposisi $A A^{1}$ & $\begin{array}{c}\text { Berat } \\
\text { Molekul } \\
\text { dalam Da } \\
(\text { Jumlah AA })^{2}\end{array}$ \\
\hline 1 & aS1-Kasein & $\begin{array}{l}\text { P02662, } \\
\text { terverifikasi }\end{array}$ & $\begin{array}{l}\text { MKLLILTCLVAVALARPKHPIKHQGLPQEVLNENLLRFFVAP } \\
\text { FPEVFGKEKVNELSKDIGSESTEDQAMEDIKQMEAESISSS } \\
\text { EEIVPNSVEQKHIQKEDVPSERYLGYLEQLLRLKKYKVPQL }\end{array}$ & $\begin{array}{l}24528,87 \\
\text { (214 AA) }\end{array}$ \\
\hline
\end{tabular}

EIVPNSAEERLHSMKEGIHAQQKEPMIGVNQELAYFYPELF RQFYQLDAYPSGAWYYVPLGTQYTDAPSFSDIPNPIGSEN SEKTTMPLW

2 aS2-Kasein P02663, MKFFIFTCLLAVALAKNTMEHVSSSEESIISQETYKQEKNMA terverifikasi INPSKENLCSTFCKEVVRNANEEEYSIGSSSEESAEVATEE VKITVDDKHYQKALNEINQFYQKFPQYLQYLYQGPIVLNPW

(222 AA) DQVKRNAVPITPTLNREQLSTSEENSKKTVDMESTEVFTKK TKLTEEEKNRLNFLKKISQRYQKFALPQYLKTVYQHQKAMK PWIQPKTKVIPYVRYL

$3 \quad \beta$ - Kasein

$5 \quad \beta$-Laktoglobulin

P02754, terverifikasi

P02668, terverifikasi

P02666, MKVLILACLVALALARELEELNVPGEIVESLSSSEESITRINK KIEKFQSEEQQQTEDELQDKIHPFAQTQSLVYPFPGPIPNS LPQNIPPLTQTPVVVPPFLQPEVMGVSKVKEAMAPKHKEM PFPKYPVEPFTESQSLTLTDVENLHLPLPLLQSWMHQPHQ PLPPTVMFPPQSVLSLSQSKVLPVPQKAVPYPQRDMPIQA FLLYQEPVLGPVRGPFPIIV

MMKSFFLVVTILALTLPFLGAQEQNQEQPIRCEKDERFFSD KIAKYIPIQYVLSRYPSYGLNYYQQKPVALINNQFLPYPYYA KPAAVRSPAQILQWQVLSNTVPAKSCQAQPTTMARHPHP HLSFMAIPPKKNQDKTEIPTINTIASGEPTSTPTTEAVESTVA TLEDSPEVIESPPEINTVQVTSTAV

MKCLLLALALTCGAQALIVTQTMKGLDIQKVAGTWYSLAMA ASDISLLDAQSAPLRVYVEELKPTPEGDLEILLQKWENGEC AQKKIIAEKTKIPAVFKIDALNENKVLVLDTDYKKYLLFCMEN SAEPEQSLACQCLVRTPEVDDEALEKFDKALKALPMHIRLS FNPTQLEEQCHI

$6 \quad \alpha$-Laktalbumin

P00711, MMSFVSLLLVGILFHATQAEQLTKCEVFRELKDLKGYGGVS terverifikasi

LPEWVCTTFHTSGYDTQAIVQNNDSTEYGLFQINNKIWCK DDQNPHSSNICNISCDKFLDDDLTDDIMCVKKILDKVGINY WLAHKALCSEKLDQWLCEKL

$7 \quad$ Laktoferin

P24627, terverifikasi MKLFVPALLSLGALGLCLAAPRKNVRWCTISQPEWFKCRR WQWRMKKLGAPSITCVRRAFALECIRAIAEKKADAVTLDG GMVFEAGRDPYKLRPVAAEIYGTKESPQTHYYAVAVVKKG SNFQLDQLQGRKSCHTGLGRSAGWIIPMGILRPYLSWTES LEPLQGAVAKFFSASCVPCIDRQAYPNLCQLCKGEGENQC ACSSREPYFGYSGAFKCLQDGAGDVAFVKETTVFENLPEK ADRDQYELLCLNNSRAPVDAFKECHLAQVPSHAVVARSVD GKEDLIWKLLSKAQEKFGKNKSRSFQLFGSPPGQRDLLFK DSALGFLRIPSKVDSALYLGSRYLTTLKNLRETAEEVKARY TRVVWCAVGPEEQKKCQQWSQQSGQNVTCATASTTDDC IVLVLKGEADALNLDGGYIYTAGKCGLVPVLAENRKSSKHS SLDCVLRPTEGYLAVAVVKKANEGLTWNSLKDKKSCHTAV DRTAGWNIPMGLIVNQTGSCAFDEFFSQSCAPGADPKSRL CALCAGDDQGLDKCVPNSKEKYYGYTGAFRCLAEDVGDV AFVKNDTVWENTNGESTADWAKNLNREDFRLLCLDGTRK PVTEAQSCHLAVAPNHAVVSRSDRAAHVKQVLLHQQALF GKNGKNCPDKFCLFKSETKNLLFNDNTECLAKLGGRPTYE EYLGTEYVTAIANLKKCSTSPLLEACAFLTR

Keterangan: ${ }^{1}$ Penamaan AA berdasarkan sistem satu huruf; ${ }^{2}$ Perhitungan berat molekul menggunakan perangkat lunak PROTEIN CALCULATOR v3.4 yang dibuat oleh The Scripps Research Institute, USA (http://protcalc.sourceforge.net)

\section{Simulasi pemotongan protein sekuen meng- gunakan PeptideCutter}

Protein susu sebagai sumber peptida aktif di hidrolisis in silico berbasis laman web pada simula- tor PeptideCutter dari portal ExPASy. Enzim proteolitik GIS yang digunakan adalah pepsin, tripsin, dan kimotripsin. Setiap protein susu ini akan dipotong menggunakan tujuh (7) kombinasi enzim ((i) pepsin, 
(ii) tripsin, (iii) kimotripsin, (iv) pepsin+tripsin, (v) pepsin+kimotripsin, (vi) tripsin+kimotripsin, dan (vii) pepsin+tripsin+ kimotripsin) secara terpisah. Dengan demikian total simulasi yang dilakukan adalah 49 simulasi (tujuh jenis protein susu dan tujuh jenis kombinasi enzim). Untuk menggambarkan proses dan informasi hasil pemotongan menggunakan simulator PeptideCutter, contoh hasil simulasi pemotongan $\alpha$-laktalbumin dengan enzim pepsin $(\mathrm{pH} 1.3)$ dapat dilihat pada Tabel 2.

Tabel 2 menunjukkan jika $\alpha$-laktalbumin dihidrolisis dengan enzim pepsin $(\mathrm{pH} \mathrm{1,3)} \mathrm{maka} \mathrm{terdapat}$ 142 kemungkinan fragmen peptida ataupun AA yang dihasilkan. Fragmen-fragmen peptida inilah yang kemudian akan dianalisis lebih lanjut kesesuaian urutan dan komposisi AA nya terhadap fragmen peptida bioaktif yang ada pada pangkalan data yang dapat diakses dari laman BIOPEP (http://www.uwm.edu.pl/ biochemia) (Iwaniak dan Dziuba, 2011). Secara umum, informasi berupa jenis enzim pemotong, posisi pemotongan, sekuen peptida hasil pemotongan, jumlah AA dan berat molekul peptida secara umum didapatkan untuk setiap simulasi pemotongan menggunakan ketujuh kombinasi enzim yang telah disebutkan di atas.

\section{Peptida hasil pemotongan dan aktivitas biologis- nya}

Hasil simulasi pemotongan protein susu dapat berupa asam amino, dipeptida, oligo- maupun polipeptida. Penyusunan hasil pemotongan dilakukan berdasarkan huruf pertama kombinasi AA untuk memudahkan proses pencarian aktivitas biologis dari peptida hasil simulasi tersebut melalui pangkalan data. Gambar 2 menunjukkan jumlah peptida hasil pemotongan untuk setiap kombinasi enzim yang digunakan. Jumlah peptida hasil pemotongan berbanding lurus dengan berat molekul dari protein susu yang dipotong. Jumlah (fragmen) peptida yang terbesar dihasilkan dari laktoferin yang merupakan protein susu yang terbesar, yakni memiliki berat molekul 78056,14 Da (Tabel 1). Total fragmen peptide atau $A A$ hasil pemotongan laktoferin menggunakan ketujuh kombinasi perlakuan enzim di atas adalah 970 fragmen. Protein $\alpha$-laktalbumin yang memiliki berat molekul terkecil (16246,56 Da) juga memiliki jumlah fragmen hasil pemotongan yang terkecil, yakni sebesar 217 fragmen.

Tabel 2. Contoh hasil simulasi pemotongan $\alpha$-laktalbumin dengan enzim pepsin $(\mathrm{pH} 1,3)$

\begin{tabular}{|c|c|c|c|}
\hline Posisi Pemotongan & Sekuen Peptida Hasil Pemotongan & Jumlah AA & Berat Molekul (Da) \\
\hline 3 & MMS & 3 & 367,48 \\
\hline 4 & $\mathrm{~F}$ & 1 & 165,19 \\
\hline 6 & VS & 2 & 204,23 \\
\hline 7 & $\mathrm{~L}$ & 1 & 131,18 \\
\hline 8 & $\mathrm{~L}$ & 1 & 131,18 \\
\hline 9 & $\mathrm{~L}$ & 1 & 131,18 \\
\hline 12 & VGI & 3 & 287,36 \\
\hline 13 & $\mathrm{~L}$ & 1 & 131,18 \\
\hline 14 & $\mathrm{~F}$ & 1 & 165,19 \\
\hline 21 & HATQAEQ & 7 & 783,80 \\
\hline 22 & $\mathrm{~L}$ & 1 & 131,18 \\
\hline 27 & TKCEV & 5 & 578,68 \\
\hline 28 & $\mathrm{~F}$ & 1 & 165,19 \\
\hline 30 & RE & 2 & 303,32 \\
\hline 33 & LKD & 3 & 374,43 \\
\hline 42 & LKGYGGVSL & 9 & 893,05 \\
\hline 49 & PEWVCTT & 7 & 834,94 \\
\hline 50 & $\mathrm{~F}$ & 1 & 165,19 \\
\hline 70 & HTSGYDTQAIVQNNDSTEYG & 20 & 2200,21 \\
\hline 71 & $\mathrm{~L}$ & 1 & 131,18 \\
\hline 72 & $\mathrm{~F}$ & 1 & 165,19 \\
\hline 98 & QINNKIWCKDDQNPHSSNICNISCDK & 26 & 3018,34 \\
\hline 99 & $\mathrm{~F}$ & 1 & 165,19 \\
\hline 103 & LDDD & 4 & 476,44 \\
\hline 104 & $\mathrm{~L}$ & 1 & 131,18 \\
\hline 123 & TDDIMCVKKILDKVGINYW & 19 & 2254,68 \\
\hline 124 & L & 1 & 131,18 \\
\hline 133 & AHKALCSEK & 9 & 986,15 \\
\hline 134 & $\mathrm{~L}$ & 1 & 131,18 \\
\hline 137 & DQW & 3 & 447,45 \\
\hline 138 & L & 1 & 131,18 \\
\hline 141 & CEK & 3 & 378,44 \\
\hline 142 & L & 1 & 131,18 \\
\hline
\end{tabular}




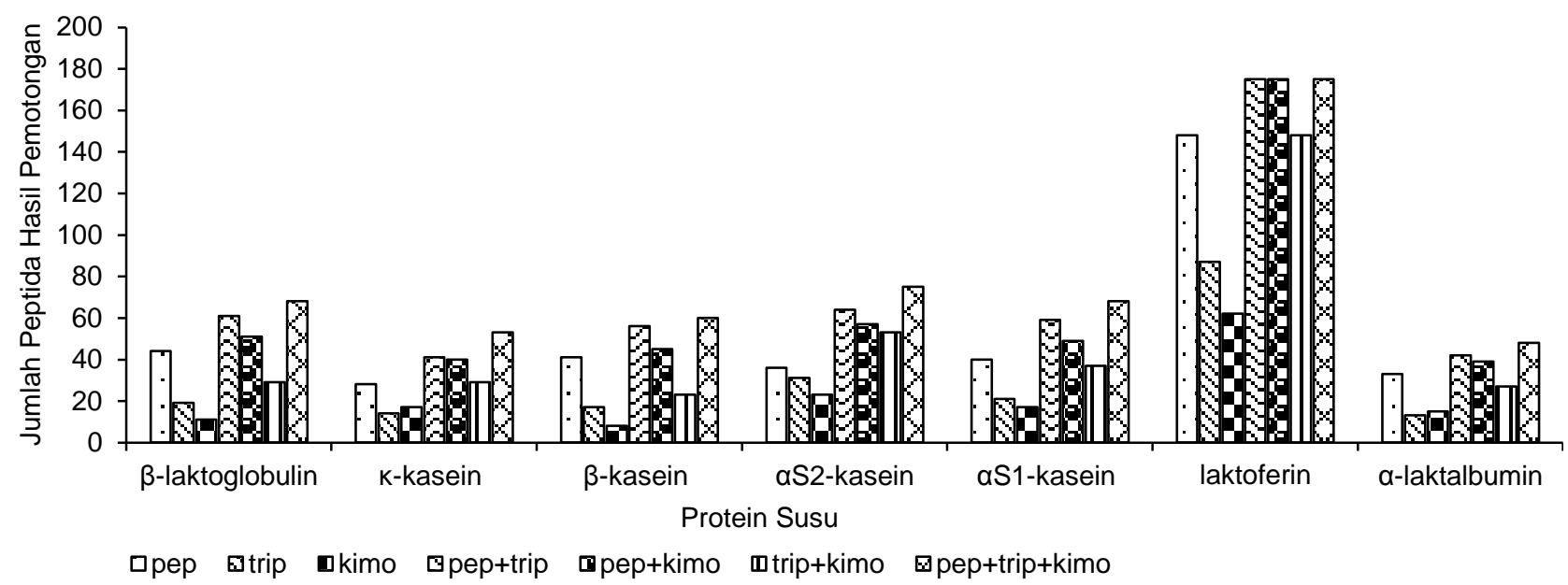

Gambar 2. Jumlah (fragmen) peptida hasil pemotongan dari berbagai protein susu menggunakan berbagai kombinasi enzim ( $p e p=$ pepsin, trip=tripsin, kimo=kimo-tripsin)

Menggunakan fungsi vlookup yang tersedia pada perangkat lunak Microsoft Excel, maka peptida bioaktif hasil pemotongan dari berbagai protein susu menggunakan berbagai kombinasi enzim dapat ditabulasikan. Gambar 3 menunjukkan bahwa peptida bioaktif hasil pemotongan memiliki variasi dalam jumlah berdasarkan kombinasi enzim pemotongnya. Kombinasi tiga enzim simulasi (pepsin+tripsin+ kimotripsin) tidak selalu memberikan jumlah peptida bioaktif hasil pemotongan yang tertinggi. Hidrolisis $\beta$-laktoglobulin menggunakan kombinasi enzim pepsin+tripsin+kimotripsin menghasilkan jumlah peptida bioaktif tertinggi, yakni sebanyak lima fragmen peptida bioaktif. Sementara hidrolis $\beta$-kasein menggunakan pepsin juga menghasilkan peptida bioaktif tertinggi, yakni lima fragmen. Protein aS2kasein yang dipotong menggunakan kombinasi tripsin+kimotripsin hanya menghasilkan dua peptida bioaktif. Protein aS1-kasein yang memiliki berat molekul 24528,87 Da dapat menghasilkan enam peptida bioaktif jika dihidrolisis menggunakan kombinasi pepsin+kimotripsin. Khusus untuk k-kasein, kombinasi enzim pepsin+tripsin; tripsin+kimotripsin; pepsin +kimotripsin; dan menggunakan tripsin menghasilkan jumlah peptida bioaktif yang sama.

Enzim pepsin, tripsin dan kimotripsin merupakan edopeptidase. Tripsin umumnya memotong ikatan peptida setelah adanya AA lisin dan arginin pada rantai polipeptida pada sisi terminal $\mathrm{C}$ (Korhonen, 2009a). Sementara kimotripsin memotong ikatan peptida setelah adanya AA dengan berat molekul besar yang bersifat hidrofobik seperti tirosin, triptofan, metionin maupun leusin (Dziuba et al., 2009). Sebagai bagian dari endopeptidase, pepsin relatif tidak spesifik, walaupun dalam beberapa kondisi pepsin akan memotong ikatan peptida setelah adanya AA yang bersifat hidrofobik (Minkiewicz et al., 2008). Perbedaan spesifitas dari ketiga GIS inilah yang mengakibatkan hidrolisis protein susu menggunakan kombinasi tiga enzim sekaligus (pepsin+tripsin+ kimotripsin) tidak selalu menghasilkan fragmen peptida terbesar.

Secara persentase (Gambar 4), dengan menggunakan tujuh (7) kombinasi dari enzim pemotong, $\beta$-kasein memiliki persentase peptida bioaktif hasil pemotongan yang tertinggi, yakni $52 \%$, yang diikuti dengan aS1-kasein (48\%) dan $\beta$-laktoglobulin $(41 \%)$. Berdasarkan penelusuran literatur ilmiah, fungsi peptida bioaktif yang telah dilaporkan yang berasal dari berbagai protein susu memiliki 13 bioaktivitas, yakni antihipertensi, antibakteri, antiamnestik, antikarsinogenik, antitrombotik, antioksidan (Dziuba et al., 2009), antivirus, imunomodulator (Gobbetti et al., 2002), regulator, inhibitor DPP IV (Korhonen, 2009a), pengikat mineral, opioid, serta opioid antagonis (Vercruysse et al., 2009).

Berdasarkan pengelompokan aktivitas ini, pada Gambar 5 disajikan persentase bioaktivitas dari berbagai protein susu hasil hidrolisis menggunakan GIS in silico. Semua jenis protein susu dapat menjadi sumber antihipertensi dan telah dilaporkan dalam literatur lain (Mohanty dan Mohapatra, 2016). Sebagai sumber peptida bioaktif yang terbesar, $\beta$-kasein merupakan sumber antioksidan dan immunomodulator dan inhibitor DPP IV (Minkiewicz et al., 2008). Hasil yang serupa juga telah dilaporkan oleh Dziuba dan Iwaniak (2009). Selain ketiga aktivitas di atas, pemotongan $\beta$-kasein in silico menggunakan pangkalan data BIOPEP yang dikembangkan oleh Departemen Biokimia Pangan, Universitas Warmia dan Mazury di Olsztyn, Polandia (www.uwm.edu.pl/ biochemia) juga menghasilkan aktivitas opioid, opioid antagonis, antiamnestik, antitrombotik maupun sebagai regulator fungsi mukosa (Dziuba et al., 2009). 


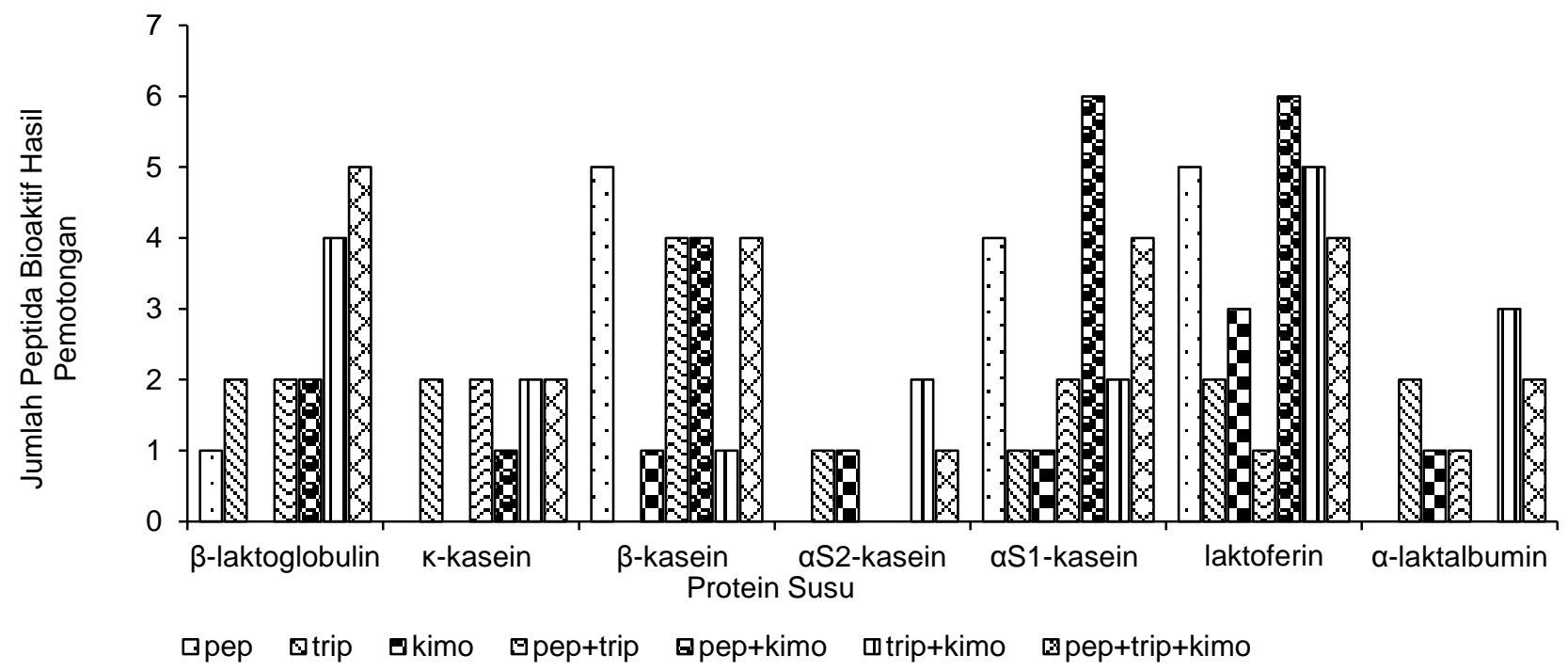

Gambar 3. Jumlah peptida bioaktif hasil pemotongan dari berbagai protein susu menggunakan berbagai kombinasi enzim $(p e p=$ pepsin, trip $=$ tripsin, kimo $=$ kimotripsin $)$

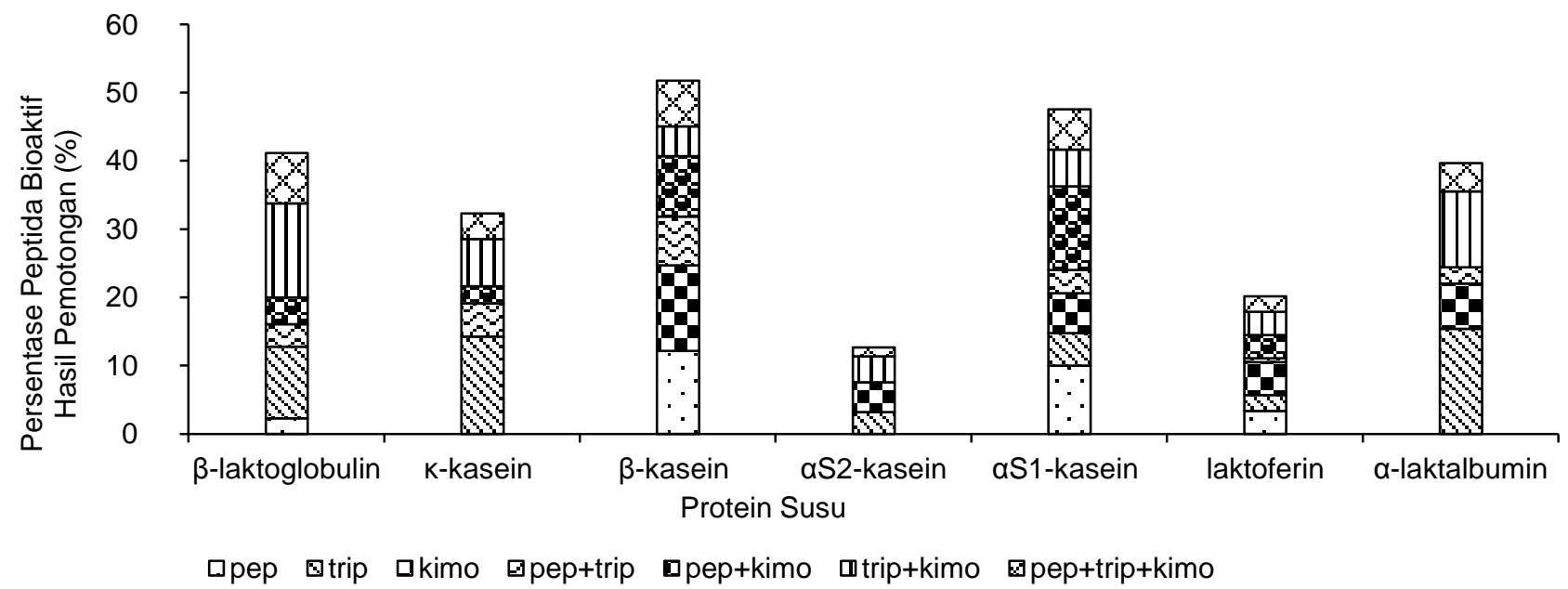

Gambar 4. Persentase peptida bioaktif hasil pemotongan dari berbagai protein susu menggunakan berbagai kombinasi enzim (pep=pepsin, trip=tripsin, kimo =kimotripsin)

Adanya perbedaan aktivitas biologis yang dihasilkan dari pemotongan $\beta$-kasein antara studi ini dengan literatur yang ada (Dziuba et al., 2009) disebabkan oleh perbedaan pada jenis, jumlah dan kombinasi enzim yang digunakan. Terdapat 24 jenis enzim proteolitik yang digunakan secara individual untuk memotong $\beta$-kasein dalam studi yang dilakukan oleh Dziuba et al. (2009). Sebagai jenis protein susu yang memiliki berat molekul yang terbesar, laktoferin dapat menjadi sumber antivirus maupun inhibitor DPP IV (Gambar 5). Laktoferin merupakan bagian dari transferrin yang telah dilaporkan memiliki sifat antimikroorganisme maupun antivirus sehingga dapat digunakan dalam pengobatan manusia maupun hewan (Bruni et al., 2016).
Hasil dari penelitian ini dapat digunakan sebagai informasi dasar/awal untuk pelaksanaan studi in vitro atau in vivo dalam penentuan aktivitas peptida bioaktif yang berasal dari susu. Variabilitas dari aktivitas-aktivitas biopeptida yang dianalisis dapat diperkecil, sehingga dalam pelaksanaan studi in vitro atau in vivo waktu yang dibutuhkan tidak terlalu lama dan biaya pengujian dapat berkurang. Strategi kombinasi studi in silico yang diikuti oleh studi in vivo atau in vitro (Sucher, 2014) telah banyak digunakan dalam eksplorasi komponen bioaktif yang berasal dari alam serta aplikasinya baik untuk pangan, disain vaksin maupun untuk keperluan imunomodulasi (Doytchinova et al., 2004). 


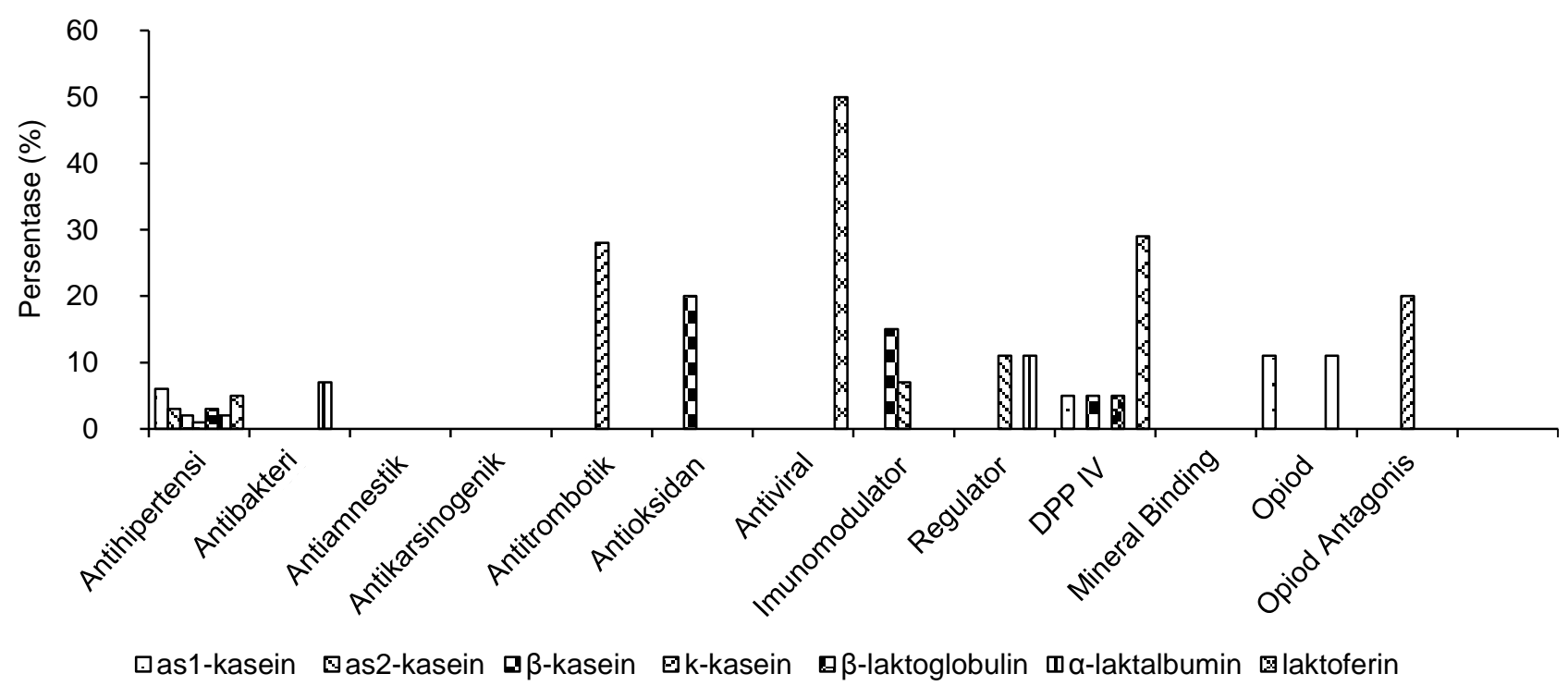

Gambar 5. Persentase bioaktivitas dari berbagai protein susu hasil hidrolisis menggunakan GIS in silico

\section{KESIMPULAN}

Teknik in silico telah digunakan untuk menduga hasil peptida bioaktif yang berasal dari protein susu. Hidrolisis protein susu oleh enzim proteolitik yang berasal dari GIS (pepsin, tripsin, dan kimotripsin) dapat dengan mudah dilakukan menggunakan perangkat lunak PeptideCutter yang tersedia pada portal Expert Protein Analysis System (ExPASy) Molecular Biology Server. Dari hasil simulasi, semua jenis protein susu ( $\alpha$ S1-kasein, $\alpha S 2-k a s e i n, \quad \beta$ kasein, dan $\mathrm{k}$-kasein (golongan kasein) serta $\beta$ laktoglobulin, $\alpha$-laktalbumin, dan laktoferin (golongan whey)) dapat menjadi sumber peptida bioaktif yang memiliki aktivitas antihipertensi. Berdasarkan hasil proteolisis in silico dari studi ini, $\beta$-kasein dan aS1kasein merupakan sumber peptida bioaktif yang tertinggi dibandingkan dengan protein susu lainnya. Jumlah dan aktivitas peptida bioaktif hasil pemotongan dalam studi ini (menggunakan PeptideCutter) memiliki perbedaan dengan metode in silico lainnya yang berbasis laman web (lihat Dziuba et al., 2009). Perbedaan ini terjadi karena jenis, jumlah dan kombinasi enzim yang digunakan dalam proses pemotongan. Hasil penelitian ini diharapkan dapat diverifikasi menggunakan teknik in vivo maupun in vitro sebagai informasi tambahan yang menunjukkan potensi protein susu sebagai sumber peptida bioaktif.

\section{DAFTAR PUSTAKA}

Apweiler R. 2009. The universal protein resource (UniProt) in 2010. Nucleic Acids Res 38: 190195. DOI: $10.1093 /$ nar/gkp846.
Bruni N, Capucchio MT, Biasibetti E, Pessione E, Cirrincione S, Giraudo L, Corona A, Dosia F. 2016. Antimicrobial activity of lactoferrin-related peptides and applications in human and veterinary medicine. Molecules 21: 1-25. DOI: 10.339 0/molecules21060752.

Choi J, Sabikhi L, Hassan A, Anand S. 2012. Bioactive peptides in dairy products. Int $\mathrm{J}$ Dairy Technol 65: 1-12. DOI: 10.1111/j.14710307.201 1.00725.x.

Doytchinova IA, Walshe VA, Jones NA, Gloster SE, Borrow $P$, Flower DR. 2004. Coupling in silico and in vitro analysis of peptide-MHC binding: A bioinformatic approach enabling prediction of superbinding peptides and anchorless epitopes. J Immunol 172: 7495-7502. DOI: 10.4049/jim munol.172.12.7495.

Dziuba M, Dziuba B, Iwaniak A. 2009. Milk proteins as precursors of bioactive peptides. Acta Scientiarum Polonorum, Technologia Alimentaria. Trends Food Sci Tech 8: 71-90. DOI: 10.1016/0 924-2244(90)90029-X.

Ekins S, Mestres J, Testa B. 2007. In silico pharmacology for drug discovery: Methods for virtual ligand screening and profiling. Brit $\mathrm{J}$ Pharmacol 152: 9-20. DOI: 10.1038/sj.bjp.0707305.

Gasteiger E, Gattiker A, Hoogland C, Ivanyi I, Appel RD, Bairoch A. 2003. ExPASy: The proteomics server for in-depth protein knowledge and analysis. Nucleic Acids Res 31: 3784-3788. DOI: 10.1093/nar/gkg563.

Gobbetti M, Stepaniak L, de Angelis M, Corsetti A, di Cagno R. 2002. Latent bioactive peptides in milk proteins: Proteolytic activation and significance in dairy processing. Crit Rev Food Sci 
42: 223-239. DOI: 10.1080/104086902908255 38.

Gu Y, Majumder K, Wu J. 2011. QSAR-aided in silico approach in evaluation of food proteins as precursors of ACE inhibitory peptides. Food Res Int 44: 2465-2474. DOI: 10.1016/j.foodres. 2011.01.051.

Iwaniak A, Dziuba J. 2011. BIOPEP-PBIL tool for the analysis of the structure of biologically active motifs derived from food proteins. Food Technol Biotech 49: 118-127.

Korhonen HJ. 2009a. Milk-derived bioactive peptides: From science to applications. J Funct Food 1: 177-187. DOI: 10.1016/j.jff.2009.01.0 07.

Korhonen HJ. 2009b. Bioactive milk proteins and peptides: From science to functional applications. Aust J Dairy Technol 64: 16-25.

Korhonen HJ. 2011. Bioactive milk proteins, peptides and lipids and other functional components derived from milk and bovine colostrum. Roy Soc Ch 471-511. Woodhead Publishing Limited. DOI: 10.1533/9780857092557.3. 471.

Minkiewicz P, Dziuba J, Iwaniak A, Dziuba M, Darewicz M. 2008. BIOPEP database and other programs for processing bioactive peptide sequences. J AOAC Int 91: 965-980.

Mohanty DP, Mohapatra S. 2016. Milk derived bioactive peptides and their impact on human health - a review. Saudi J Biol Sci 23: 577-583. DOI: 10.1016/j.sjbs.2015.06.005.

Nagpal R, Behare P, Rana R, Kumar A, Arora S, Morotta F, Jain S, Yadav H. 2011. Bioactive peptides derived from milk proteins and their health beneficial potentials: An update. Food Funct 2: 18-27. DOI: 10.1039/COFO00016G.

Sánchez A, Vázquez A. 2017. Bioactive peptides - a review. Food Qual Saf 1: 29-46. DOI: 10.1093/f qsafe/fyx006.

Sitanggang $A B$, Drews A, Kraume M. 2016. Development of a continuous membrane reactor process for enzyme-catalyzed lactulose synthesis. Biochem Eng J 109: 65-80. DOI: 10. 1016/j.bej.2016.01.006.

Sucher NJ. 2014. Searching for synergy in silico, in vitro and in vivo. Synergy 1: 30-43. DOI: 10.10 16/j.synres.2014.07.004.

Tulipano G, Faggi L, Nardone A, Cocchi D, Caroli AM. 2015. Characterisation of the potential of $\beta$ lactoglobulin and $\alpha$-lactalbumin as sources of bioactive peptides affecting incretin function: In silico and in vitro comparative studies. Int Dairy J 48: 66-72. DOI: 10.1016/j.idairyj.2015.01.008.

Vercruysse L, van Camp J, Dewettinck K, Smagghe G. 2009. Production and Enrichment of Bioactive Peptides Derived from Milk Proteins. 51-67. Woodhead Publishing Limited. DOI: 10.1533/ 9781845697198.1.51. 